\author{
MARIUSZ KRAWCZYK \\ ORCID: 0000-0002-5961-1629 \\ Uniwersytet Jagielloński \\ mariusz.krawczyk@uj.edu.pl
}

\title{
Związki publicznoprawne a podmiotowość w wykonywaniu władzy publicznej na tle myśli Tadeusza Bigi
}

\begin{abstract}
Abstrakt: Tekst dotyczy podmiotowości w wykonywaniu władzy publicznej na przykładzie związków publicznoprawnych (samorządów). Podmioty te wykazują pewną specyfikę z uwagi na ich zdecentralizowaną postać i działanie w ramach zasady samodzielności. Nie chodzi jednak o wymiar strukturalno-organizacyjny, lecz o moment wykonywania władczych uprawnień. W tym obszarze zasady działania władz samorządowych są takie same jak innych podmiotów publicznych. Różnica sprowadza się zasadniczo do możliwości kreowania własnej polityki przez samorządy i zakresu władzy dyskrecjonalnej.
\end{abstract}

Słowa kluczowe: władza publiczna, decentralizacja, samodzielność samorządu, podmiotowość władzy.

\section{Uwagi wprowadzające}

Na samym początku rozważań wystarczy zauważyć, że dawna (ale tylko w pewnym sensie) myśl prawnicza stanowi ogromne dziedzictwo pozwalające zrozumieć, usystematyzować i zinterpretować współczesne problemy nauki prawa. To wartość sama w sobie, ponieważ ,przeszłość ma znaczenie w poznawaniu prawa. Paradoks polegający na zmienności, ulotności regulacji prawnych i ciągłości, trwałości myśli prawnej można między innymi wyjaśnić odniesieniem [...] do

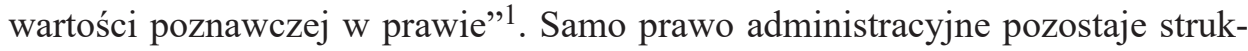

1 J. Jeżewski, Wartość poznawcza dawnych poglądów nauki prawa administracyjnego $w$ projekcie współczesnego sposobu myślenia, [w:] Wartości w prawie administracyjnym, red. J. Zimmermann, Warszawa 2015, s. 141. 
turą ukształtowaną na drodze swoistego rozwoju ${ }^{2}$. Są dzieła, które traktować należy nie tylko jako zapis niegdysiejszego porządku prawnego i związanych z nim poglądów, ale też jako skarbnicę wyobrażeń i idei warunkujących współczesność, a zarazem przesądzających o niej. Takim dziełem jest niezaprzeczalnie monografia autorstwa Tadeusza Bigi, Zwiąki publiczno-prawne w świetle ustawodawstwa polskiego, wydana w Warszawie w 1928 roku.

\section{$* * *$}

Badać władzę publiczną można z wielu perspektyw, posługując się różnymi założeniami, odwołując się do różnych jej aspektów, wskazując różne punkty odniesienia. Jednym z możliwych ujęć staje się kwestia organizacyjnego podziału w strukturze wykonywania władzy czy też wykazywanie specyfiki poszczególnych typów podmiotów wyposażonych w możliwość uczestniczenia we władzy i sięgania do jej atrybutów. Już intuicyjnie da się wyczuć, że pewne rozwiązania sprzyjają „rozciąganiu” zakresu takiego udziału — na różnych jego poziomach. Mówiąc jeszcze inaczej, niektóre rodzaje — już w tym momencie można użyć takiego stwierdzenia — władz administracyjnych budowane są w oparciu o określoną niejako z góry podmiotowość wykonywania funkcji władzy.

$\mathrm{Na}$ tym tle, nie tylko od strony teorii, ale przede wszystkim wobec współczesnego prawodawstwa międzynarodowego, europejskiego i krajowego, uwidacznia się rola tych bytów, które zakwalifikujemy jako samorząd, a już na pewno samorząd terytorialny (powszechny). W kwestii ustaleń terminologicznych, odwołując się do myśli Bigi, stwierdzić musimy, co połączy się od razu z podmiotowością w wykonywaniu władzy publicznej, że

samorząd [...] jest zdecentralizowaną administracją, wykonywaną przez samodzielne związki. Zatem związki publ.-prawne są związkami samorządowymi. Związki publiczno-prawne i związki samorządowe - to dwa synonimy: zakresy tych nazw pokrywają się. Samorząd jest oznaczeniem formy administracji, wyraża stosunek osób administrujących do państwa, określa tylko jedną relację podmiotu administracji. Związek publ.-prawny jest oznaczeniem samego podmiotu administracji ${ }^{3}$.

2 Natomiast refleksja o historycznym charakterze pozwala udzielić odpowiedzi na wiele istotnych pytań co do dzisiejszych efektów tego rozwoju. Widać to bardzo wyraźnie w odniesieniu do konstrukcji samorządu a „reaktywowany w Polsce samorząd terytorialny [...] odpowiada zarówno definicji samorządu sformułowanej przez T. Bigę, jak też spełnia podstawowe tezy uzupełniające tę definicję" - J. Jendrośka, Koncepcja samorządu terytorialnego T. Bigo, [w:] Związi komunalne $w$ Polsce $i$ w państwach Europy Zachodniej, Materiaty konferencji naukowej zorganizowanej dla uczczenia pamięci Profesora Doktora Tadeusza Bigo, red. A. Błaś, „Przegląd Prawa i Administracji” 35, 1996, s. 21.

3 T. Bigo, Związki publiczno-prawne w świetle ustawodawstwa polskiego, Warszawa 1928, s. 154.

Prawo 333, 2021

(C) for this edition by CNS 


\section{Ponadto jeszcze w przedmiocie ustaleń wprowadzających:}

istotą wzajemnego zrównoważonego stosunku państwa i samorządu jest współcześnie rozumienie samorządu jako jednego ze sposobów pluralizacji władzy, co jest elementem ustroju demokratycznego. [...] Samorząd nie powinien więc być traktowany jako techniczny sposób rozproszenia sprawowania władzy w państwie, ale jako istotny element konstrukcji samego państwa demokratycznego i prawnego, zwiększający jego stabilność ${ }^{4}$.

Klamrą spinającą uwagi wprowadzające niech będzie zachowujące pełną aktualność stwierdzenie, że ,związek publ.-prawny — w rozumieniu polskiego ustawodawstwa - jest to związek uposażony w władztwo administracyjne i powołany do życia przez państwo wzgl. przy jego czynnym udziale"5; władztwo administracyjne to "sprawdzian charakteru publ.-prawnego związku”6. Nie jest celem opracowania odnoszenie się do rozumienia czy zakresu samego władztwa administracyjnego ${ }^{7}$; zakładamy, że związek (samorząd) z istoty swojej powołany zostaje do uczestniczenia we władzy publicznej i forma ta wykazuje jakieś implikacje w wymiarze zakresu wykonywania takiej władzy (władztwa).

\section{Upodmiotowienie}

\section{Kategoria podmiotowości jest wieloznaczna. Z jednej strony}

upodmiotowienie prawne [...] oznacza taki rezultat regulacji ustrojowego prawa administracyjnego, w którym wyodrębnienia prawne i strukturalno-organizacyjne czyni możliwym (późniejsze) przyporządkowywanie funkcji, władztwa administracyjnego i zadań publicznych oraz kompetencji (z tym że te ostatnie docelowo powinny trafić do organów administracji publicznej — zatem proces wyodrębnienia kompetencyjnego zakończy się dopiero po ustanowieniu organów podmiotów administracji publicznej) $)^{8}$.

4 I. Lipowicz, Samorzad terytorialny XXI wieku, Warszawa 2019, s. 198.

5 T. Bigo, Zwiazki publiczno-prawne..., s. 82.

${ }^{6}$ Ibidem, s. 80. Nie jest to jednak, jak stwierdza Bigo, prawo do imperium czy prawo do władztwa - ibidem, s. 142.

${ }^{7}$ Kategoria „władztwa administracyjnego” to jedna z najbardziej fundamentalnych kwestii w nauce prawa administracyjnego, na przestrzeni dziesięcioleci akcentowano różne jej aspekty. Bigo stwierdzał, że „przez władztwo administracyjne rozumieć należy moc wydawania jednostronnych zarządzeń i rozkazów, które posiadają przywilej domniemania ważności i wprowadzania ich w życie przy użyciu bezpośredniego przymusu. Jest to cecha zasadnicza, która jest pomocna przy przeprowadzeniu granicy pomiędzy administracją, jako działalnością prywatną, a więc na przykład gdy chodzi o stwierdzenie, czy prawne związki, korporacje lub instytucje mają charakter publicznoprawny, czy prywatny. Przez przymus bezpośredni w tym znaczeniu rozumieć należy przywilej, iż władze administracyjne nie muszą się zwracać do sądów o zastosowanie środków egzekucyjnych przy wprowadzaniu w życie aktu administracyjnego" — idem, Polskie prawo administracyjne. Część ogólna (stenogram wykładów uniwersyteckich), [Lwów 1932], s. 14.

${ }^{8}$ P. Lisowski, Samodzielność jednostek samorzadu terytorialnego (kluczowe aspekty terminologiczno-pojęciowe i konstrukcyjne), [w:] Prawne problemy samorządu terytorialnego z perspektywy 25-lecia jego funkcjonowania, red. B. Jaworska-Dębska, R. Budzisz, Warszawa 2016, s. 24-25.

Prawo 333, 2021

(C) for this edition by CNS 
Z drugiej zaś, nie wchodząc nazbyt w szczegóły tych ustaleń, wymaga rozróżnienia pojęcia osoby prawa publicznego i podmiotu prawa publicznego czy też nieutożsamiania pojęcia podmiotowości prawnej (publicznoprawnej, administracyjnoprawnej) i pojęcia osobowości publicznoprawnej, to znaczy „każda osoba prawa publicznego jest podmiotem prawa publicznego, ale nie każdy podmiot prawa publicznego jest osobą prawa publicznego"".

Jeżeli chodzi o atrybuty związku publicznoprawnego (samorządu), to - ponownie, nie odnosząc się do różnych sposobów uzasadniania takiego stwierdzenia — „tem co indywidualizuje samorząd i wyodrębnia z pośród administracji jest osobowość prawa jednostek samorządowych"10. Z kolei „ustawą oznaczony zakres działania [na przykład - M.K.] gminy jest czemś więcej niż kompetencją organu rządowego. Jest to kompleks praw i obowiązków gminy, które one wykonują we własnem imieniu, jako własne prawa i obowiązki, a nie w charakterze organu innej osoby prawnej"11. Ponadto podmiotami administracji samorządowej mogą być jedynie osoby prawne korporacyjnie zorganizowane, czyli związki ${ }^{12}$. Z tego względu, jeśli mowa o ,podmiotowości” i na przykładzie samorządu terytorialnego, ,,podmiotowość samorządu terytorialnego należy rozpatrywać co najmniej w dwóch zakresach", to znaczy, że istnieje potrzeba „wyodrębnienia podmiotowości samej wspólnoty samorządowej niezależnie od podmiotowości (osobowości prawnej) j.s.t."13.

Powyższe ustalenia wychodzą od perspektywy prawa ustrojowego (w wymiarze konstytucyjnym i niższego rzędu). Celem opracowania jest zwrócenie uwagi na inny jeszcze wymiar podmiotowości, to znaczy podmiotowości w wykonywaniu

${ }^{9}$ I. Skrzydło-Niżnik, Model ustroju samorzadu terytorialnego w Polsce na tle zagadnień ustrojowego prawa administracyjnego, Kraków 2007, s. 276. Por. rozważania Bigo dotyczące kategorii osoby prawnej, gdzie odnaleźć można, że „osobowość prawna jest jedna w całym obszarze prawa. Jest to zdolność stawania się podmiotem praw i obowiązków" - idem, Związki publiczno-prawne..., s. $27 \mathrm{n}$.

10 T. Bigo, Związi publiczno-prawne..., s. 141. Zob. ibidem, s. 129.

11 Ibidem.

12 Ibidem, s. 151.

13 K. Bandarzewski, O podmiotowości wspólnot samorzadowych, [w:] Podmiotowość samorzadu terytorialnego - ustrojowe pytania i dylematy, red. M. Stec, K. Małysa-Sulińska, Warszawa 2020, s. 69 i 70. Warto zwrócić uwagę jeszcze na wypowiedź odnosząca się do samej istoty samorządu: „Tym właśnie różni się samorząd terytorialny od administracji rządowej, której istnienie i funkcjonowanie skierowane jest do adresatów (będą nimi także mieszkańcy wspólnot samorządowych), ale nie jest uzależnione od woli tych mieszkańców; realizując zadania publiczne, administracja rządowa kieruje się celami wyznaczanymi przez naczelne i centralne organy administracji rządowej, a nie interesami wspólnot lokalnych” — ibidem, s. 72. Z kolei „przedmiot samorządowej administracji nie różni się od przedmiotu administracji rządowej; $z$ tego punktu widzenia nie można przeciwstawiać administracji samorządowej — administracji państwowej, bo samorząd jest tylko odmienną formą organizacyjną administracji państwowej" — T. Bigo, Związki publiczno-prawne..., s. 140. Zob. również ibidem, s. 126. W dzisiejszej perspektywie na potrzeby odróżnienia tego przedmiotu da się wykorzystać formułę „zaspokajania potrzeb wspólnoty samorządowej”, ale ono może okazać się zawodne. Nie przedmiot a wymiar takich zadań okazuje się istotny — por. wyrok TK z dnia 25 lipca 2006 roku, sygn. K 30/04, OTK-A 2006, nr 7, poz. 86. 
władzy, choć należy pamiętać, że ma ona swoje zakotwiczenie również w aspekcie strukturalno-organizacyjnym. Mając świadomość pewnych odmienności pojęciowych we współczesności, możemy przytoczyć, że ,gmina ma cały szereg praw podmiotowych, które zapewniają jej zawiadywanie pewnemi działami administracji według jej uznania, a wyrażają się potencjalnie w zakazach pod adresem władz rządowych; dzięki tym prawom powstaje pewna sfera wolności gminy; w jej granicach gmina ma "prawo stanowienia« $[\ldots]$ tj. prawo decydowania według własnego uznania"14. W charakterystyce tego zakresu w literaturze pojawia się pojęcie samodzielności, a „problematyka prawnych zakresów samodzielności działania administracji staje się aktualna zarówno jako problem badawczy, jak i problem praktyczny, związany ściśle ze współczesnym renesansem doktryny państwa prawa"15. Wydaje się jednak, że samodzielność pozostaje wśród atrybutów natury organizacyjnej, to znaczy opisuje stworzone i konstrukcyjne warunki do przyszłego dopiero wykonywania administracji. Być może będzie to niepotrzebne mnożenie pojęć, ale jeżeli będziemy chcieli odnieść się już tylko do „konsumowania” tych warunków ${ }^{16}$, to uzasadnione stanie się także mówienie o podmiotowości - upodmiotowieniu w wykonywaniu władzy jako efekcie samodzielności ${ }^{17}$.

\section{Zdecentralizowanie}

Kategoria decentralizacji również jest wieloznaczna, przynajmniej jeżeli chodzi o pola wiedzy, na których się jej używa. Decentralizacja prawno-administracyjna oznacza „taki system — w którym istnieje większa ilość ośrodków administracji publicznej” i chodzi tu o ośrodki, ,samodzielne podmioty sprawujące administrację"18. „O decentralizacji możemy mówić wtedy, gdy podmioty administrujące są źródłami [...] działalności, to znaczy — gdy samodzielnie ją

14 T. Bigo, Związi publiczno-prawne..., s. 147.

15 A. Błaś, Studia z nauki prawa administracyjnego i nauki administracji, „Prawo” 263, 1998, s. 48 .

16 Opieram się tu na terminologii P. Lisowskiego, op. cit., s. 25.

17 Jeszcze inaczej i z innej perspektywy można powiedzieć, że to upodmiotowienie będzie miało różne źródła, natomiast samodzielność — wobec ustaleń literatury z zakresu administracyjnego prawa ustrojowego - łączy się powszechnie z elementami natury strukturalnej i ustrojowej. Zob. np. rozważania Błasia, prowadzone w kontekście różnych zależności organizacyjnych pomiędzy różnymi podmiotami administracji publicznej — idem, op. cit., s. 44-46. Bigo pisał z kolei, że jedynym miernikiem samodzielności są przepisy o nadzorze — zob. idem, Z problematyki nadzoru nad organami administracji terenowej, [w:] Rozprawy prawnicze. Ksiega pamiatkowa dla uczczenia pracy naukowej Kazimierza Przybyłowskiego, red. W. Osuchowski, M. Sośniak, B. Walaszek, Kraków 1964, s. 27-32. Por. idem, Z problemów nadzoru nad administracją terenowa, „Kontrola Państwowa" 1964, s. 22-23.

18 T. Bigo, Związki publiczno-prawne..., s. 121. Dodatkowo „oczywista, aby można mówić o decentralizacji, musi istnieć choćby jedna wspólna norma; w przeciwnym razie mielibyśmy do 
rozwijają” i polega to na „zniesieniu podporzadkowania” władzy centralnej ${ }^{19}$. Mamy tu zatem do czynienia z interpretacją i systematyzowaniem ,jakości” powiązań. Nie budzi także zastrzeżeń stwierdzenie, że samorząd nie jest tożsamy z decentralizacją, to znaczy samorząd stanowi jedynie (aczkolwiek mający niebagatelne znaczenie) jeden $z$ typów decentralizacji ${ }^{20}$ czy sposobów jej urzeczywistniania. Ponownie uwidaczniają się tu ustrojowe i strukturalne podstawy, ponieważ „decentralizacja nie ma nic wspólnego z wyobrażeniami treści działalności administracyjnej; [...] opiera się ona na momentach strukturalnych; moment treści okazuje się zgoła nieistotny" ${ }^{21}$. Nie można jednak powiedzieć, by nie miało to żadnego przełożenia na moment „konsumowania” określonych uprawnień władczych 22 .

Rozważania Bigi były prowadzone na gruncie Konstytucji marcowej ${ }^{23}$; dzisiejsza sytuacja wygląda o tyle odmiennie, że decentralizacja władzy publicznej zostało wprost podniesiona do rangi konstytucyjnej zasady ustrojowej ${ }^{24}$ i z tego względu odnosi się nie tylko do samorządu ${ }^{25}$, ale całego ustroju terytorialnego państwa. W każdym razie

czynienia z większą ilością systemów równorzędnych, a wyrazy: centralizacja i decentralizacja w odniesieniu do takiego przypadku - nie miałaby wcale zastosowania ani żadnego sensu" - ibidem.

19 Ibidem, s. 122. A. Błaś stwierdza, że „decentralizacja jest samodzielnością kreowaną zawsze przez ustawodawcę, nie zaś przez przełożonego służbowego. Przełożony służbowy nie może ograniczać zakresu samodzielności, która podmiot administrujący uzyskał od ustawodawcy. Nie może także wpływać na sposób korzystania z przyznanej ustawowo samodzielności [...]. Prawnie określone środki, które mogą w ściśle określonym ustawowo zakresie ograniczyć samodzielność podmiotu administrującego zdecentralizowanego, są jedynie środkami nadzoru" - idem, op. cit., s. 45.

20 T. Bigo, Zwiazki publiczno-prawne..., s. 124.

21 Ibidem, s. 123.

22 Samodzielność można rozumieć jako atrybut o dynamicznej proweniencji — będzie się bowiem ujawniać w administrowaniu. „Z kolei określenie «samodzielny» wykazuje już bardziej statyczne (instytucjonalne) konotacje — zwrot ten służyć może [...] do charakteryzowania tego, kto korzysta z dostępu do samodzielnego administrowania. Samodzielność przejawia się zatem przedmiotowo, docelowo jednak ukierunkowana jest podmiotowo" - P. Lisowski, Samodzielność w administrowaniu, [w:] Decentralizacja i centralizacja administracji publicznej. Współczesny wymiar w teorii i praktyce, red. B. Jaworska-Dębska, E. Olejniczak-Szałowska, R. Budzisz, Warszawa-Łódź 2019, s. 92.

${ }^{23}$ Ustawa z dnia 17 marca 1921 roku — Konstytucja Rzeczypospolitej Polskiej, Dz.U. Nr 44, poz. 267, akt archiwalny. W interesującym nas zakresie zob. w szczególności art. 66, 67 i 70.

24 Mówi o tym art. 15 ust. 1 ustawy z dnia 2 kwietnia 1997 roku - Konstytucja Rzeczypospolitej Polskiej, Dz.U. Nr 78, poz. 483 z późn. zm.: „Ustrój terytorialny Rzeczypospolitej Polskiej zapewnia decentralizację władzy publicznej”, co koresponduje także z zasadą pomocniczości (wrażoną w preambule). Na marginesie można dodać, że szereg rozwiązań z Konstytucji marcowej przypomina przynajmniej ustalenia współczesnej konstytucji, samą decentralizację wyinterpretowalibyśmy z jej art. 67. Jednakże wprost Konstytucja marcowa mówiła tylko o „dekoncentracji” (art. 66 zd. pierwsze).

${ }^{25}$ Inny pogląd prezentowany jest w większości komentarzy do Konstytucji: „,Wprawdzie konstytucyjne pojęcie władzy publicznej jest szerokie i obejmuje wszystkie władze RP — ustawodawczą, wykonawczą i sądowniczą, to w kontekście art. 15 ust. 2 należy przyjąć, że zasada ta dotyczy decentralizacji władzy publicznej realizowanej w postaci samorządu terytorialnego" - B. Bana-

Prawo 333, 2021

(C) for this edition by CNS 
decentralizacja, o której stanowi Konstytucja Rzeczypospolitej Polskiej nie jest jednorazowym przedsięwzięciem organizacyjnym, lecz trwałą cechą kultury politycznej państwa zbudowanej na właściwych rozwiązaniach ustawowych, zgodnych z konstytucyjnymi zasadami ustroju Rzeczypospolitej. [...] Decentralizacja nie może być rozumiana w sposób mechaniczny, w oderwaniu od kontekstu interpretacyjnego stanowiącego konsekwencję całokształtu zasad i wartości konstytucyjnych składających się na ustrój państwa. Odnosi się to zwłaszcza do odpowiedzi na pytanie o granice decentralizacji ${ }^{26}$.

W tym miejscu należy zwrócić jeszcze uwagę na ustalenia natury metodologicznej, które wskazuje Bigo. Przy ustalaniu istoty samorządu „metoda indukcyjna, którą posługuje się wielu autorów, nie prowadzi do zadowalających rezultatów”; „dlatego należy [...] szukać ustalenia tego pojęcia na innej drodze, mianowicie na drodze logicznej analizy wyobrażeń o cechach samorządu"27. Z drugiej strony ,problem związków publ.-prawnych traktować można wyłącznie z punktu widzenia prawa pozytywnego, a nie teoretycznego"28. Wiemy już, że ustalenia dotyczą podmiotów zdecentralizowanych, co znajduje swe odzwierciedlenie $\mathrm{w}$ wielu wypowiedziach ustrojodawcy, na czele $\mathrm{z}$ zasadą wyrażoną w art. 15 ust. 1 Konstytucji RP. Ponownie chodzi o wymiar strukturalno-organizacyjny a odbiciem decentralizacji jest wskazywana już (ustrojowa) samodzielność ${ }^{29}$. Oba te zakresy należy zaś uznać za wyznaczony przepisami Konstytucji i ustaw prawnych oraz praktyczny fundament wykonywania władzy publicznej przez związki publiczno-prawne (samorządy).

\section{Zakres podmiotowości}

Nie jest nazbyt odkrywczym stwierdzenie, że poszczególne funkcje, zadania przypisane - w naszym wypadku — związkom (samorządom) realizowane są przez odpowiednie organy ${ }^{30}$. Posługując się sformułowaniem Bigi, możemy stwierdzić, że każda osoba prawna, w tym państwo, rozwija swoją działalność

szak, Konstytucja Rzeczypospolitej Polskiej. Komentarz, Warszawa 2012, s. 133. Por. P. Tuleja, Komentarz do art. 15, [w:] Konstytucja Rzeczypospolitej Polskiej. Komentarz, red. P. Tuleja, Warszawa 2019, s. 73-74.

26 Wyrok TK z dnia 18 lutego 2003 roku, sygn. K 24/02, OTK-A 2003, nr 2, poz. 11.

27 T. Bigo, Zwiąki publiczno-prawne..., s. 148 i 149.

28 Ibidem, s. 51.

29 „Istotnym elementem definicyjnym decentralizacji jest prawnie chroniona samodzielność podmiotów bezpośrednio korzystających z decentralizacji” — H. Izdebski, Ustrój terytorialny Rzeczypospolitej Polskiej i zasada decentralizacji, [w:] Ustrój terytorialny państwa a decentralizacja systemu władzy publicznej, red. A. Lutrzykowski, Toruń 2012, s. 16-17.

${ }^{30}$ Nawet, gdy spojrzymy na tak zwany substrat osobowy - mieszkańców, wspólnotę, to ich upodmiotowienie w każdych okolicznościach znajduje jakieś połączenie z organami samorządowymi. Wystarczy tu prosty przykład: ustawa z dnia 15 września 2000 roku o referendum lokalnym, Dz.U. z 2019 r. poz. 741, przy przedmiocie tego referendum odsyła na przykład do „sposobu rozstrzygania sprawy dotyczącej tej wspólnoty”, ale „mieszczącej się w zakresie zadań i kompetencji organów danej jednostki” (art. 2 ust. 1 pkt 2).

Prawo 333, 2021

(C) for this edition by CNS 
za pośrednictwem organów ${ }^{31}$. Nie ma przy tym zasadniczej różnicy pomiędzy organami administracji samorządowej i organami administracji rządowej, jeżeli chodzi o sposoby i zasady kreowania ich działań, przynajmniej na płaszczyźnie stricte prawnej. Różnice spotkamy gdzie indziej, na przykład w odniesieniu do wyboru obsady personalnej. Abstrahując od modelu (typu) leżącego u podstaw konstruowania samorządu w naszych realiach, organy samorządowe objęte są tymi sami regułami, co wszystkie inne podmioty władzy publicznej, między innymi zasadą legalności czy związaniem ustawowym, to znaczy nie ma kompetencji organów samorządowych poza tymi, które znajdują swoje podstawy w ustawie.

Zwróćmy uwagę teraz na normy zadaniowe, które nakazują realizację lub dążenie do osiągniecia pewnego celu — określają zadania sformułowane najczęściej w powiązaniu z celem działania ${ }^{32}$. Zadania $^{33}$ (obowiązki wynikające z norm zadaniowych) realizowane są jedynie przez zespół określonych kompetencji i to kompetencje w ostateczności decydują o możności (zdolności) działania ${ }^{34}$. Można co najwyżej powiedzieć, że w określonych okolicznościach istnieje możliwość dostosowania — wyboru środków (kompetencji — form działania) realizacji określonych zadań przez upodmiotowiony byt wykonujący władzę publiczną (organ). Uzasadnione jest stwierdzenie, że

stan swobody charakterystyczny dla samodzielności [...] może dotyczyć zarówno funkcjonowania administracji publicznej w fazie jej ,organizowania się”, jak i zmierzaniu do osiągnięcia celów zewnętrznych stawianych przed tego typu strukturami. [...] Legitymowanie się samodzielnością w tej sui generis fazie wstępnej (wewnętrznej) sprzyja samodzielności docelowego — zewnętrznego już administrowania ${ }^{35}$.

Okazuje się jednak, że z punktu widzenia mechanizmów rządzących działaniami organów samorządowych nie odnajdziemy w stosunku do nich formalnych różnic względem pozostałych podmiotów władzy ${ }^{36}$. To ustawodawca bowiem decyduje o możliwościach realizacji zadań samorządowych (jak i o samych zadaniach $^{37}$ ), wyposażając organy samorządowe w odpowiednie kompetencje, to

31 Por. T. Bigo, Związki publiczno-prawne..., s. 131.

32 W. Jakimowicz, Wykładnia w prawie administracyjnym, Warszawa-Kraków 2006, s. 413.

$33 \mathrm{Na}$ temat pojęcia zadania publicznego zob. G. Samitowski, Koncepcja systemu zadań publicznych w ramach gminnej gospodarki odpadami komunalnymi, niepublikowana praca doktorska, Uniwersytet Jagielloński, Kraków 2017, s. 33-44. Autor wprowadził podział zadań na zadania: analityczne, organizatorskie, kierunkujące i kontrolne - zob. ibidem, s. $51 \mathrm{n}$.

34 „W oparciu o normę zadaniową organ zobowiązany jest do dokonywania wszelkich działań, które umożliwiają realizację nakazanego stanu rzeczy, jakkolwiek do dokonywania [na przykład - M.K.] czynności konwencjonalnych doniosłych prawnie konieczne jest uzyskanie przezeń dodatkowo kompetencji do dokonywania tych czynności” - W. Jakimowicz, Wykładnia ..., s. 414.

35 P. Lisowski, Samodzielnośćc..., s. 91-92.

36 Można jeszcze dodać, że, ,jeśli przypisujemy jednostkom samorządowym osobowość, to nie dlatego, jakoby one były jakiemiś suwerennymi organizacjami, lecz poprostu dlatego, że są podmiotami praw" - T. Bigo, Zwiazki publiczno-prawne..., s. 129.

37 W tym zakresie nie ma zasadniczo znaczenia podziała zadań na zadania własne i zlecone, choć pamiętać należy, że tak naprawdę tylko w granicach zadań własnych można mówić o samo- 
znaczy możliwości posługiwania się formami działania; swoistość przejawia się zaś nie tyle w sposobie realizacji działań, co — najczęściej — w treści sformułowanych upoważnień.

Odwołując się teraz wprost do samorządu terytorialnego, który we współczesnych uregulowaniach jest formą najbardziej „rozwiniętą”, zwracamy uwagę, że samorząd ten wykonuje przypisane mu zadania „w imieniu własnym i na własną odpowiedzialność" ${ }^{38}$. Nie ma to jednak bezpośredniego przełożenia na prawny sposób określenia realizacji przypisanych funkcji. W niektórych momentach zwrot ten przybierze już jedynie postać „metaprawnej” kwalifikacji dla poczynań organów samorządowych. Co to oznacza? Nie budzi wątpliwości, że przywołanego stwierdzenia $z$ Konstytucji i ustaw samorządowych nie można rozumieć dosłownie ${ }^{39}$. Wydaje się, że chodzi tu o możliwość samodzielnego określania i wykonywania polityki komunalnej (lokalnej, regionalnej) — w połączeniu z interesami mieszkańców ${ }^{40}$. Z perspektywy prawnej najważniejszy będzie poziom korzystania z przyznanych kompetencji i środków co przełoży się na władzę dyskrecjonalną i ewentualną fakultatywność działań ${ }^{41}$.

W tym zakresie nie mają znaczenia wypowiedziane przez ustrojodawcę i ustawodawcę tak zwane domniemania kompetencji, które już tylko determinują obszar możliwych działań a nie ich istotę. Da się to oczywiście połączyć w podmiotowością w wykonywaniu władzy, którą poza wskazywanym ujęciem - w pewnym sensie — ,jakościowym” ilustruje również „podmiotowość ilościowa”, to znaczy ilość merytorycznie wyznaczonych obszarów na danym szczeblu struktury, któ-

rządzie - ibidem, s. 193. Zakres zadań zleconych staje się „usamorządowieniem” wykonywania określonych działań „na pewien czas”.

38 Formuła wypowiedziana w art. 16 ust. 2 in fine Konstytucji RP, którą powtarzają ustawy samorządowe: art. 2 ust. 1 ustawy z dnia 8 marca 1990 roku o samorządzie gminnym, Dz.U. z 2020 r. poz. 713 z późn. zm.; art. 2 ust. 1 ustawy z dnia 5 czerwca 1998 roku o samorządzie powiatowym, Dz.U. z 2020 poz. 920; art. 6 ust. 1 pkt 1 ustawy z dnia 5 czerwca 1998 roku o samorządzie województwa, Dz.U. z 2020 r. poz. 1668 z późn. zm. Jest to także standard międzynarodowy określony w art. 3 ust. 1 Europejskiej Karty Samorządu Lokalnego z dnia 15 października 1985 roku, ratyfikowanej 26 kwietnia 1993 roku (Dz.U. z 1994 r. Nr 124, poz. 607, sprost. Dz.U. z 2006 r. Nr 154, poz. 1107). W pozostałych obszarach samorządu spotkamy już inne wypowiedzi ustawodawcy, ale w swej treści mające podobny cel, np. art. 2 ust. 2 ustawy z dnia 1 lipca 2011 roku o samorządzie pielęgniarek i położnych, Dz.U. z 2021 r. poz. 628, mówi, że „Samorząd jest niezależny w wykonywaniu swoich zadań i podlega tylko przepisom prawa".

39 Zob. J. Zimmermann, Prawo administracyjne, Warszawa 2020, s. 261.

40 Zwracano na to uwagę już w dawnej literaturze - zob. K. Krzeczkowski, Gmina jako podmiot polityki komunalnej, „Samorząd Terytorialny” 1938, nr 3, s. 30-31.

41 Władztwo administracyjne (władze administracyjną) można rozumieć jako „tkwiące” w kompetencji administracyjnej, przez co sprowadzające się do wykonawczej roli administracji oraz jako władztwo w stosunku do kompetencji — zob. I. Skrzydło-Niżnik, Istota i rodzaje władczych uprawnień administracji państwowej, „Krakowskie Studia Prawnicze” 1987, nr 20, s. 127. W praktycznym wymiarze popatrzmy tu na przykład na tak zwane uchwały kierunkowe (wydawane chociażby przez radę gminy na podstawie art. 18 ust. 2 pkt 2 u.s.g.), które wskazują organom wykonawczym możliwe sposoby wykorzystywania należnych im kompetencji 
rych dotyczą wypowiedzi danej władzy, albo „ilość” adresatów tych działań ${ }^{42}$. Samorząd jako taki otrzymać może jedynie pewien wycinek obszaru zainteresowania państwa (względnie państwo „zaakceptuje” obecność jakiegoś podmiotu w tym obszarze) albo ukonstytuowany zostanie ogólnie — poprzez przekazanie przynajmniej istotnej części zadań publicznych (samorząd terytorialny, powszechny ${ }^{43}$ ).

Podsumowując tę część rozważań, stwierdzić możemy, że ustawa, która nakłada na samorząd zadania (obowiązki), winna być skonstruowana w taki sposób, by w jakimś zakresie pozostawić organom samorządu prawo do decydowania o sposobie ich wykonywania ${ }^{44}$. Samodzielność ustrojowa powinna jakoś przekładać się na podmiotowość w wykonywaniu władzy, ale nie ma, co należy podkreślić, bezpośredniej implikacji pomiędzy tymi elementami. Na pewno w świetle współczesnych zasad nieuzasadniona jest teza o naturalistycznej czy „umiarkowanie naturalistycznej” koncepcji samorządu ${ }^{45}$, co mogłoby mieć przełożenie na możliwość kreowania podstaw swojego działania ${ }^{46}$. Uogólniając słowa Jakimowicza, możemy powiedzieć, że o istnieniu i zakresie władzy administracyjnej decyduje ustawodawca $\mathrm{z}$ jednej strony wyznaczający granice samodzielności samorządu, a z drugiej strony kreujący kompetencje jego organów ${ }^{47}$.

\section{Przejawy}

Nie da się siłą rzeczy odnieść w ograniczonych ramach artykułu do wszelkich ważnych tu elementów. Reprezentatywnym obszarem dla ukazania omawianej w opracowaniu istoty stać się może planowanie i zagospodarowanie przestrzenne i pozycja gminy w tym zakresie. W literaturze i orzecznictwie dla opisania tego

42 Również w wymiarze terytorialnym, zob. rozważania J. Korczaka w kwestii władztwa terytorialnego — idem, Władztwo terytorialne gminy. Od idei do mitu, „Ruch Prawniczy, Ekonomiczny i Socjologiczny" 2020, nr 4, s. 97-110.

43 „Powszechność” to nie tylko ex lege udział wszystkich w takim samorządzie, ale także odniesienie do zakresu działania. Wobec poczynionych ustaleń można jeszcze dodać, że „tylko gmina [w dzisiejszej perspektywie i powiat i województwo samorządowe - M.K.] rozwija działalność z natury swej podobną do działalności państwowej. Inne związki (nieterytorjalne) działają tylko w obrębie pewnego koła osób, członków" - T. Bigo, Związki publiczno-prawne..., s. 172. I działania te dotyczą już tylko sprecyzowanego zadania/zadań, na przykład sprawowanie pieczy nad należytym wykonywaniem zawodu.

44 Wyrok TK z dnia 25 lipca 2006 roku...

45 Por. H. Izdebski, op. cit., s. 29. Jest to zgodne z ogólnym ujmowanie istoty samorządu przez T. Bigo.

46 Można mieć wątpliwości czy dozwolone jest na przykład mówienie o tak zwanych zadaniach „oddolnych” - por. G. Samitowski, op. cit., s. 89 n.

47 Stwierdzenie W. Jakimowicza wobec władztwa planistycznego gminy - idem, O normatywnych podstawach wladztwa planistycznego gminy, [w:] Kierunki reformy prawa planowania i zagospodarowania przestrzennego, red. I. Zachariasz, Warszawa 2012, s. 72. 
przypadku używa się określenia władztwa planistycznego gminy, które realizowane jest przede wszystkim w postaci formy — aktu generalnego/normatywnego - aktu prawa miejscowego - miejscowego planu zagospodarowania przestrzennego ${ }^{48}$. Zauważyć można jeszcze, że „ważnym rodzajem władztwa samorządowego jest władztwo prawodawcze. To ono wynosi samorząd terytorialny ponad inne rodzaje władztwa w państwie" 49 . Zadaniem gminy jest tu ,sprawa ładu przestrzennego" (art. 7 ust. 1 pkt 1 ab initio u.s.g.). Plan przyjmuje się w sformalizowanej i szczegółowo ustalonej procedurze - zakres kompetencji rady gminy do uchwalenia planu ulokowano zasadniczo w art. 15 ust. 2 (obligatoryjne elementy planu) i 3 (fakultatywne elementy planu) ustawy z dnia 27 marca 2003 roku o planowaniu i zagospodarowaniu przestrzennym ${ }^{50}$. „Władztwa planistycznego nie można zatem opierać wyłącznie [...] na zadaniach publicznych powierzonych do wykonania gminie" i nie do zaakceptowania jest pogląd, zgodnie z którym

nie można racjonalnie założyć, że każda czynność organu gminy podejmowana w ramach przyznanego jej władztwa planistycznego wymaga konkretnego przepisu upoważaniającego. Przyjęcie takiego poglądu oznaczałoby przekreślenie istoty władztwa, u podstaw którego leży samodzielne decydowanie o przeznaczeniu i zasadach zagospodarowania określonych obszarów ${ }^{51}$.

Wskazywane tu władztwo ma być realizowane zatem na podstawie ściśle określonych warunków i można mieć wątpliwości, czy w niektórych przynajmniej planach pewne ustalenia „nie idą zbyt daleko” przy powołaniu się na samodzielność. To prawda, że występujące na przykład w art. 15 ust. 2 u.p.z.p. pojęcia mają charakter niedookreślony, ale ich wykładnia nie może być dowolna ${ }^{52}$. Aktualność zachowuje stwierdzenie, że ,zakres własny został zdeterminowany według przedmiotu, poruczony zaś według źródła, skąd czerpie moc obowiązu-

48 W przypadku jego braku „zastępowany” jest przez decyzję o warunkach zabudowy i zagospodarowania terenu. W orzecznictwie i literaturze budzi wątpliwości prawny charakter tej decyzji, to znaczy — czy jest aktem związanym czy swobodnym. Nie przesądzając tego zagadnienia, stwierdzić musimy, że z pewnością nie można uzasadniać jej „dowolności” ustrojową konstrukcją samodzielności — por. I. Zachariasz, Komentarz do art. 59 u.p.z.p., [w:] H. Izdebski, I. Zachariasz, Ustawa o planowaniu i zagospodarowaniu przestrzennym. Komentarz, LEX/el. 2013, pkt 5; J. Goździewicz-Biechońska, Decyzja o warunkach zabudowy i zagospodarowania terenu (cechy szczególne), „Państwo i Prawo” 2010, nr 2, s. 102-104.

49 I. Lipowicz, op. cit., s. 221.

50 Dz.U. z 2021 r. poz. 741 z późn. zm.

51 W. Jakimowicz, Władztwo planistyczne gminy - kompetencje, zadania, wolności, „Administracja. Teoria - Dydaktyka - Praktyka” 2012, nr 1 (26), s. 17.

52 Praktycznie każdy plan określa ograniczenia w zakresie kąta nachylenia i kształtu dachu typu wskazanej zabudowy. Będzie to element związany z „zasadami kształtowania zabudowy” (art. 15 ust. 2 pkt 6 ab initio u.p.z.p.), ale już w kontekście „zasad kształtowania krajobrazu” (art. 15 ust. 2 pkt 3a u.p.z.p.) nie jest niezbędny. Zdarza się, że na terenach z przewagą zabudowy (jednorodzinnej, wielorodzinnej) o dachach płaskich, zwłaszcza na terenach zurbanizowanych, plany wobec nowej zabudowy jednorodzinnej wymagają dachu dwuspadowego lub wielospadowego (najczęściej o nachyleniu połaci od $35^{\circ}$ do $45^{\circ}$ ). Nie mówiąc już o wielu nakazach/zakazach związanych z wyglądem zewnętrznym elewacji. 
jącą" 53 , jednakże i zakres własny musi być wykonywany nie tylko w granicach tego przedmiotu, ale i na podstawie zdeterminowanego prawnie upoważnienia w odniesieniu do tego przedmiotu.

Tradycyjnie kategorię władzy (władztwa) postrzega się przez pryzmat tych działań administracji, które z pozycji autorytatywnej jednostronnie i w bezpośredni sposób kształtują sytuację prawną podmiotów zewnętrznych (tak, jak w przykładzie dotyczącym miejscowego planu zagospodarowania przestrzennego) i są zabezpieczone możliwością przymusowego wykonania (w odniesieniu do obowiązków). Wydaje się jednak, że dzisiejsza władza administracji posiada znacznie więcej przejawów ${ }^{54} \mathrm{i}$ uzasadnione jest także mówienie o przymusie o ekonomiczno-socjologicznym charakterze ${ }^{55}$. Nie rozwijając tego wątku, musimy zwrócić uwagę, że kolosalne znaczenie ma tu sposób organizowania wykonywania zadań przypisanych samorządom, co znajduje swoje ujście w działaniach faktycznych ${ }^{56}$. Te z kolei decydują przynajmniej o czasie i sposobie, ,jakości” i efektywności realizacji przez podmioty zewnętrzne należnych im praw i wolności ${ }^{57}$. Uwidacznia się tu także rola tak zwanej administracji świadczącej i znaczenie samorządów powszechnych, które organizując usługi publiczne, istotnie przesądzają o stopniu „Zaspokajania zbiorowych potrzeb wspólnoty”. Nieco inaczej przedstawia się to w stosunku do samorząáw specjalnych, których władza pozostaje bliżej tradycyjnie rozumianego jądra władczości ${ }^{58}$.

53 T. Bigo, Związki publiczno-prawne..., s. 194.

54 Por. M. Krawczyk, Podstawy władztwa administracyjnego, Warszawa 2016, passim. Wskazują na to także wczesne ustalenia dotyczące samorządu terytorialnego (gminy) i ich późniejsze adaptacje — zob. J. Korczak, władztwo terytorialne..., s. 100-101. Zob. również wymiary (rodzaje) władztwa, które w literaturze wskazuje się w odniesieniu do samorządu terytorialnego - idem, Władztwo jako podstawa samodzielności jednostek samorzadu terytorialnego, [w:] Władztwo administracyjne. Administracja publiczna w sferze imperium i w sferze dominium, red. J. Łukasiewicz, Rzeszów 2012, s. 279-302.

55 J. Łętowski, Prawo administracyjne. Zagadnienia podstawowe, Warszawa 1990, s. 204205. Przy tym „dychotomia administracja władcza-niewładcza traci stopniowo swoje znaczenie; potencjalna władczość jest obecna stale w każdym działaniu władzy publicznej”; „należy zgodzić się z tymi autorami, którzy ukazują podział na władcze i niewładcze formy działania jako »zwietrzały« - lepiej bowiem w świetle badań socjologii administracji rozumiemy możliwość ukrytego władczego oddziaływania przy pozornej »nie władczości«" - I. Lipowicz, op. cit., s. 215 i 219.

56 Co łączy się także z odpowiedzialnością władz samorządowych za zaspokajanie określonych potrzeb - zob. D. Wacinkiewicz, Podmiotowość samorząu terytorialnego a zaspokajanie potrzeb wspólnoty samorzadowej, [w:] Podmiotowość samorządu terytorialnego a zakres jego dziatań i kompetencji, red. M. Stec, K. Małysa-Sulińska, Warszawa 2020, s. 20-21.

57 M. Krawczyk, Podstawy..., s. 358.

58 To znaczy poza możliwością reprezentowania interesów swoich członków (tu także pewne znaczenie opisanych działań odnajdziemy, ale już w innej zupełnie skali niż przy samorządzie powszechnym), w ich wypadku chodzi najczęściej o „zastępcze” reprezentowanie państwa wobec grupy tworzącej taki samorząd $w$ formach klasycznie władczych (dodatkowo występują tu różnice w odniesieniu do samorządów zawodowych i gospodarczych); zob. np. art. 6 ustawy z dnia 14 grudnia 1995 roku o izbach rolniczych, Dz.U. z 2018 r. poz. 1027. 
Nie ma tu sprzeczności z ustaleniami poprzednimi; wbrew pewnej linii rozumowania występującej w literaturze, działania faktyczne mogą być podejmowane jedynie na podstawie kompetencji, które w tym akurat zakresie pozostają najczęściej — z uwagi na treść — ogólnymi klauzulami kompetencyjnymi ${ }^{59}$.

W każdym razie i zwłaszcza w stosunku do samorządu terytorialnego na tym polu należy poszukiwać istoty „pionowego” podziału władzy w państwie, to znaczy w tym zakresie polityka lokalna/regionalna (ewentualnie dotycząca wykonywania jakiegoś zawodu zaufania publicznego albo prowadzenia działalności jakiegoś rodzaju) urzeczywistniana przez określone decyzje (w tym miejscu nie chodzi o decyzje administracyjne), na przykład co do realizowanych przedsięwzięć służących wykonywaniu zadań na podstawie klauzul kompetencyjnych, zastępuje lub uzupełnia decyzje (centralnej) władzy politycznej. Takie stwierdzenie co do kreowania polityki można odnieść nie tylko do omówionych tu działań faktycznych — będzie ona także „tłem” działań prawnych, jednak nie w tym sensie, że pozwoli „rozciągać” (przy powołaniu na samodzielność) treść przyznanych kompetencji, ale stanie się sposobem ustalania wyborów w zakresie ich realizacji ${ }^{60}$. Uważam, że w tym sensie Bigo pisał, że „związki samorządowe mają prawo stanowienia"61.

\section{Zamiast konkluzji}

Bigo na zakończenie swych rozważań pisał - pojawiają się poglądy mówiące, że „rozwój demokracji sprowadzić $[. .$.$] musi niechybnie zanik [...] de-$ centralizacji”, ale „jeśli doskonałą demokracja oznacza zespolenie (identyfikację) jednostki ze zbiorowością, to samorząd może być pośrednim etapem tego procesu, jego ogniwem" ${ }^{62}$. Dziś już chyba nie ma wątpliwości, że samorząd łączy się z ideami demokratycznymi ${ }^{63}$. Wykonywana w jego ramach władza otrzymuje „podwójną legitymację i legitymizację demokratyczną”.

Nie jest łatwo wykreślić pełen zakres samorządności, jednakże musi być on wyprowadzany z aktualnie obowiązującego prawodawstwa międzynarodowego, europejskiego i przede wszystkim krajowego:

Władztwo zostało udzielone jednostkom samorządu terytorialnego dla realizacji zadań publicznych, które państwo powierzyło samorządowi. Każdy z jego przejawów jest silnie uwarun-

59 Por. M. Krawczyk, W kwestii pojmowania kompetencji administracyjnej, „Administracja. Teoria - Dydaktyka — Praktyka" 2016, nr 1 (42), s. 108-129.

${ }^{60}$ Odwołując się do przykładu z miejscowym planem zagospodarowania przestrzennego, stwierdzić możemy, że tu określona „polityka” zapisana będzie w studium uwarunkowań i kierunków zagospodarowania przestrzennego gminy.

61 T. Bigo, Zwiazki publiczno-prawne..., s. 184.

62 Ibidem, s. 218.

63 Por. I. Lipowicz, op. cit., s. 162 n. 
kowany odpowiednimi podstawami prawnymi, bowiem to nie jednostka samorządu [na przykład - M.K.] terytorialnego kształtuje treść i zakres danego władztwa, ale obowiązujące przepisy prawa w myśl [...] art. 7 Konstytucji RP ${ }^{64}$.

Nie było celem opracowania odnoszenie się to pojawiających się we współczesności prądów odwracających czasem decentralizację, chociażby w zakresie „agresywnej konkurencji” o kompetencje ze strony rządu centralnego ${ }^{65}$. Niejednokrotnie można odnieść wrażenie, że „rozciąganie” i „absolutyzowanie” rozumienia samodzielności ma być odpowiedzią na takie zjawiska.

Bez wątpienia konstrukcja samorządu (związku publicznoprawnego) wykazuje pewną swoistość z punktu widzenia podziałów władzy publicznej w państwie. Uosabia ona bowiem przekazanie czy „oddanie” jej pewnego zakresu samym zainteresowanym. Stąd konstrukcja samodzielności i niezależności, ale w wymiarze strukturalno-organizacyjnym, finansowym, itp. Samo prawo podmiotowe zbiorowości (korporacji) do samodzielnego zarządzania winno być jednak rozpatrywane na linii zbiorowość — państwo. Na tym poziomie

jeśli samorząd jest specyficzną formą administracji, mianowicie: administracją przez samodzielne związki, to pierwszorzędne znaczenie ma pytanie, jaki jest stosunek tych związków do państwa, określenie tego stosunku pozwala nam [...] na ustalenie stopnia samodzielności podmiotów samorządowych. O stosunku tym zaś decydują przepisy dotyczące nadzoru państwa nad samorządem ${ }^{66}$.

Natomiast z punktu widzenia podmiotowości w wykonywaniu władzy — jej „konsumowania”, określona specyfika wynika nie tyle z samej (tak rozumianej) samodzielności, ale z treści poszczególnych upoważnień, które pozwalając działać, muszą też pozwalać na dostosowywanie konkretnych zamierzeń do specyfiki danej zbiorowości i jej potrzeb. Chodzi zatem - podobnie jak w przypadku innych podmiotów - o władzę dyskrecjonalną i fakultatywność działań, ale w połączeniu ze specyfiką „oddania” samorządowi pewnych zakresów. Zwłaszcza zakresu zadań własnych, ale również przy zadaniach zleconych, zgodnie z wymogami zasady pomocniczości, odszukać możemy pewne „usamorządowienie”: już samo wykonywanie takich funkcji przez byty obsadzane w drodze bezpośrednich wyborów będzie o tym świadczyło.

Zatem zasady wykonywania władzy są te same ${ }^{67}$. Swoistość polega zaś na możliwości kreowania odrębnej, osobnej ,polityki” realizowania władzy, to znaczy autorytatywnego decydowania — na podstawie przyznanych kompetencji -

64 J. Korczak, Władztwo jako podstawa..., s. 302.

65 Zob. ibidem, s. 217 n.

66 T. Bigo, Zwiąki publiczno-prawne..., s. 188-189.

67 Lisowski stwierdza w rozważaniach dotyczących postępowania administracyjnego z ,czynnikiem” samorządowym: „Okazuje się bowiem, że w »normalnych« przypadkach (tzn. gdy zaangażowanie administracji samorządowej ogranicza się «tylko» do orzekania organu danej jednostki samorządu terytorialnego w znaczeniu procesowym) brakuje prawnych instrumentów do prostego przenoszenia atrybutów tej ustrojowej konstrukcji [samodzielności]" - P. Lisowski, Samodzielność jednostek samorzadu terytorialnego w postepowaniu administracyjnym, „Casus” 2015, nr 76, s. 23. 
o pewnych kwestiach tu, „na miejscu” bez bezpośredniego związania poleceniami wydanymi gdzieś wyżej, co jest charakterystyczne dla struktury pomyślanej hierarchicznie. Uwidacznia się tu także rola zadań, które połączymy z administracją świadczącą, i działań z natury swojej faktycznych.

\section{Bibliografia}

Banaszak B., Konstytucja Rzeczypospolitej Polskiej. Komentarz, Warszawa 2012.

Bandarzewski K., O podmiotowości wspólnot samorzadowych, [w:] Podmiotowość samorzadu terytorialnego - ustrojowe pytania i dylematy, red. M. Stec, K. Małysa-Sulińska, Warszawa 2020.

Bigo T., Polskie prawo administracyjne. Część ogólna (stenogram wykładów uniwersyteckich), [Lwów 1932].

Bigo T., Z problematyki nadzoru nad organami administracji terenowej, [w:] Rozprawy prawnicze. Księga pamiątkowa dla uczczenia pracy naukowej Kazimierza Przybyłowskiego, red. W. Osuchowski, M. Sośniak, B. Walaszek, Kraków 1964.

Bigo T., Z problemów nadzoru nad administracja terenowa, „Kontrola Państwowa” 1964, nr 5.

Bigo T., Zwiazki publiczno-prawne w świetle ustawodawstwa polskiego, Warszawa 1928.

Błaś A., Studia z nauki prawa administracyjnego i nauki administracji, „Prawo” 263, 1998.

Goździewicz-Biechońska J., Decyzja o warunkach zabudowy i zagospodarowania terenu (cechy szczególne), „Państwo i Prawo” 2010, nr 2.

Izdebski H., Ustrój terytorialny Rzeczypospolitej Polskiej i zasada decentralizacji, [w:] Ustrój terytorialny państwa a decentralizacja systemu władzy publicznej, red. A. Lutrzykowski, Toruń 2012.

Jakimowicz W., O normatywnych podstawach władztwa planistycznego gminy, [w:] Kierunki reformy prawa planowania i zagospodarowania przestrzennego, red. I. Zachariasz, Warszawa 2012.

Jakimowicz W., Władztwo planistyczne gminy — kompetencje, zadania, wolności, „Administracja. Teoria - Dydaktyka — Praktyka” 2012, nr 1 (26).

Jakimowicz W., Wykładnia w prawie administracyjnym, Warszawa-Kraków 2006.

Jeżewski J., Wartość poznawcza dawnych pogladów nauki prawa administracyjnego w projekcie wspótczesnego sposobu myślenia, [w:] Wartości w prawie administracyjnym, red. J. Zimmermann, Warszawa 2015.

Jendrośka J., Koncepcja samorządu terytorialnego T. Bigo, [w:] Zwiazki komunalne w Polsce $i$ w państwach Europy Zachodniej, Materiały konferencji naukowej zorganizowanej dla uczczenia pamięci Profesora Doktora Tadeusza Bigo, red. A. Błaś, „Przegląd Prawa i Administracji” 35, 1996.

Korczak J., Władztwo jako podstawa samodzielności jednostek samorzadu terytorialnego, [w:] Władztwo administracyjne. Administracja publiczna $w$ sferze imperium $i$ w sferze dominium, red. J. Łukasiewicz, Rzeszów 2012.

Korczak J., Władztwo terytorialne gminy. Od idei do mitu, „Ruch Prawniczy, Ekonomiczny i Socjologiczny" 2020, $\mathrm{nr} 4$.

Krawczyk M., Podstawy wtadztwa administracyjnego, Warszawa 2016.

Krawczyk M., W kwestii pojmowania kompetencji administracyjnej, „Administracja. Teoria — Dydaktyka - Praktyka” 2016, nr 1 (42).

Krzeczkowski K., Gmina jako podmiot polityki komunalnej, „Samorząd Terytorialny” 1938, nr 3.

Lipowicz I., Samorząd terytorialny XXI wieku, Warszawa 2019.

Prawo 333, 2021

(C) for this edition by CNS 
Lisowski P., Samodzielność w administrowaniu, [w:] Decentralizacja i centralizacja administracji publicznej. Wspótczesny wymiar w teorii i praktyce, red. B. Jaworska-Dębska, E. Olejniczak-Szałowska, R. Budzisz, Warszawa-Łódź 2019.

Lisowski P., Samodzielność jednostek samorząu terytorialnego (kluczowe aspekty terminologiczno-pojęciowe i konstrukcyjne), [w:] Prawne problemy samorzadu terytorialnego z perspektywy 25-lecia jego funkcjonowania, red. B. Jaworska-Dębska, R. Budzisz, Warszawa 2016.

Lisowski P., Samodzielność jednostek samorzadu terytorialnego w postepowaniu administracyjnym, „Casus” 2015, nr 76.

Łętowski J., Prawo administracyjne. Zagadnienia podstawowe, Warszawa 1990.

Samitowski G., Koncepcja systemu zadań publicznych w ramach gminnej gospodarki odpadami komunalnymi, niepublikowana praca doktorska, Uniwersytet Jagielloński, Kraków 2017.

Skrzydło-Niżnik I., Istota i rodzaje władczych uprawnień administracji państwowej, „Krakowskie Studia Prawnicze" 1987, nr 20.

Skrzydło-Niżnik I., Model ustroju samorządu terytorialnego w Polsce na tle zagadnień ustrojowego prawa administracyjnego, Kraków 2007.

Tuleja P., Komentarz do art. 15, [w:] Konstytucja Rzeczypospolitej Polskiej. Komentarz, red. P. Tuleja, Warszawa 2019.

Wacinkiewicz D., Podmiotowość samorządu terytorialnego a zaspokajanie potrzeb wspólnoty samorzadowej, [w:] Podmiotowość samorzadu terytorialnego a zakres jego działań i kompeten$c j i$, red. M. Stec, K. Małysa-Sulińska, Warszawa 2020.

Zachariasz I., Komentarz do art. 59 u.p.z.p., [w:] H. Izdebski, I. Zachariasz, Ustawa o planowaniu i zagospodarowaniu przestrzennym. Komentarz, LEX/el. 2013.

Zimmermann J., Prawo administracyjne, Warszawa 2020.

\title{
Public Law Association and Subjectivity in the Exercise of Public Authority in the Context of Tadeusz Bigo's Thoughts
}

\author{
Summary
}

The paper is dedicated to the subjectivity in exercising public authority on the example of public and legal associations (self-government). These entities represent some specificity due to their decentralized form and operate according to the principle of independence. However, the question is neither the structural nor organizational dimensions, but the moment of exercising authority. In this area, the principles of self-government authorities' operation are the same as those of other public bodies. The difference essentially boils down to the possibility of self-governments creating their own policies and the scope of discretionary power.

Keywords: public power, decentralization, independence of self-government, subjectivity of authority. 